\title{
PERSONAL JURISDICTION BASED ON THE LOCATION OF A SERVER: CHINESE TERRITORIALISM IN THE INTERNET ERA?
}

\author{
JIE (JEANNE) HUANG ${ }^{*}$
}

\begin{abstract}
Whether a court can exercise personal jurisdiction based on the location of a server in internet ${ }^{1}$ tort cases is a controversial issue. Its significance comes from the paradox that the internet is de-localized because it is ubiquitous, but servers are indispensable to the internet and every server has a geographic location. Since 2001, Chinese law has allowed courts to exercise personal jurisdiction solely based on the location of a server or other computing equipment in intellectual property infringement cases. Recently, it has extended this jurisdiction rule to all internet torts. This paper asks whether the location of a server should be considered the place where the tort occurs and whether this territorialbased jurisdiction rule can suffice its public-law legislative goal. It may enrich current research about technology-mediated legal challenges to private international law in two aspects. Firstly, it conducts a broad international survey by looking into laws in China, the U.S., Australia and the EU. It also analyzes where the tort occurs when servers are owned by an infringer, a third party or an infringee in domain name registration, service outsourcing, platform, cloud computing, commercial spams, etc. It concludes that in legal theory, the location of the server is not the place where an internet tort occurs. Secondly, by analyzing China's experience, it argues that, in the internet era, states have to look for private-international-law tools to advance their public policy claims.

Jie (Jeanne) Huang, Associate Professor, the University of Sydney Law School, Australia. The author is very grateful of comments received at the workshop in Renmin University Law School in 2016 and the New York International Law Week in 2017. All errors remain to be mine. The paper is part of a research project funded by the China Social Science Fund 16BFX202. The author can be reached at Jeanne.huang@sydney.edu.au.

1 For the purpose of this paper, "online," "internet" and "information networks" are exchangeable and include the internet, radio and television broadcasting networks, fixed communication networks and mobile communication networks, with computers, TV sets, fixed telephones, mobile phones and other electronic devices as receiving terminals, as well as local area networks open to the public.
\end{abstract}


However, the practice shows that the territorial-based jurisdiction rule is limited in fulfilling its pubic-law legislative goal.

Introduction. 88

Chart: Servers and other computing equipment involved in a typical internet tort case .......................................... 90

I. Chinese Law for Personal Jurisdiction Solely Based on the Location of a Server

II. Infringer's Server. 96

III. Third-Party Server 104

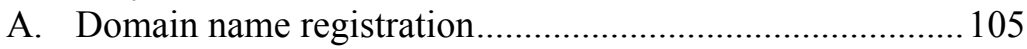

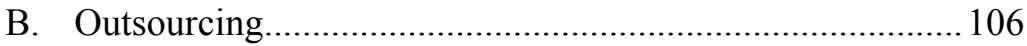

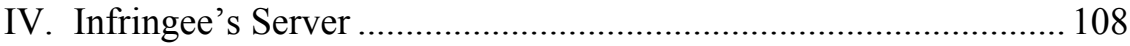

V. Legislative Reasons for Jurisdiction Based on the Location of a

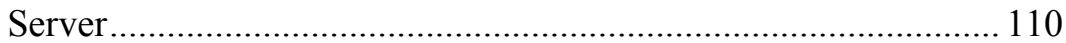

A. Data Localization and National Security ........................... 110

B. Applicable Law and Political Stability .............................. 112

VI. Can This Territorial-Based Personal Jurisdiction Rule Successfully Fulfill Its Legislative Goals? ................................... 113

A. Plaintiffs' Domicile Versus The Location of the Server .... 113

B. Deterritorial Nature of Cloud Computing...........................118

C. Exorbitant Jurisdiction....................................................... 119

VII. Conclusion and Proposal ............................................................. 120

\section{INTRODUCTION}

Whether a court can exercise personal jurisdiction over a nonresident infringer in internet tort cases, based on the geographic location of a server or other computing equipment, is an important but controversial issue. Its significance comes from the paradox that the internet is de-localized because it is ubiquitous, but servers are indispensable to the internet and every server has a geographic location. It also attracts wide attention because an internet tort not only involves private rights but also has broad public law implications on national security. For more than eighteen years, the Chinese Supreme People's Court (hereinafter "SPC") has published judicial interpretations to support Chinese courts in exercising personal jurisdiction based solely on 
the location of a server or other computing equipment. ${ }^{2}$ The Court has held that the location is the place where the tort occurs. In 2015, the Court extended this jurisdiction ground from online intellectual property ("IP") infringement cases to all internet torts. This paper examines China's experience by focusing on two questions. First, whether the location of a server should be considered the place where the tort occurs, which includes the place where the tort activity is committed and the place where the result of the tort occurs. The second is whether this territorial-based jurisdiction rule can fulfill its legislative goal.

While this paper focuses on Chinese private international law, it also has broad international implications. It may enrich current research about technology-mediated legal challenges to private international law ${ }^{3}$ in two aspects. Firstly, it conducts a broad international survey by looking into laws in China, the U.S., Australia, and the EU about personal jurisdiction based on the location of a server. It also analyzes where the tort occurs when servers are owned by an infringer, a third party or an infringee in domain name registration, service outsourcing, platform, cloud computing, commercial spams, etc. It concludes that in legal theory, the location of the server is not the place where the internet tort occurs. Secondly, by analyzing China's experience in using the

2 In the following texts, this Paper uses "server" generally to cover all equipment that may be involved in an internet tort. For a detailed discussion of Chinese law, see infra Section I.

3 E.g., Tobias Lutzi, Internet Cases in EU Private International Law-Developing a Coherent Approach, 66 INT'L \& COMP. L.Q. 687 (2017); Rita Matulionyte, Calling for Party Autonomy in Intellectual Property Infringement Cases, 9 J. PRIV. INT'L L. 77 (2013); Afzalur Rahman, Personal Jurisdiction on the Internet: A Global Perspective, 14 J. INTERNET COM. 14 (2015); Dan Jerker B. Svantesson, The Choice of Courts Convention: How Will it Work in Relation to the Internet and E-Commerce?, 5 J. PRIV. INT'L L. 517 (2009); Zheng Tang, Exclusive Choice of Forum Clauses and Consumer Contracts in E-Commerce, 1 J. PRIV. INT'L L. 237 (2005); Benedetta Ubertazzi, Intellectual Property Rights and Exclusive (Subject Matter) Jurisdiction: Between Private and Public International Law, 15 MARQ. INTELL. Prop. L. ReV. 357 (2011). Many scholars on internet personal jurisdiction do not discuss the location of the server. E.g., Andrew F. Christie, Private InTernational LaW Issues in Online Intellectual PROPERTY INFRINGEMENT Disputes WiTh CROSS-BORDER ElEMENTS: AN ANALYSIS OF NATIONAL APPROACHES 9 (2015) (using the defendant's location because the location of the defendant's equipment, such as servers, was often not identified in the survey response); Xiaoqing Feng \& Oijia Liu, Legal Problems of Internet Domain Name in China, 3 INT'L J. PRIV. L. 382 (2008) (exploring jurisdiction issues of domain name and relevant IP disputes but no discussion about the significance of the servers); Jeffrey M. Jensen, Personal Jurisdiction in Federal Courts over International E-Commerce Cases, 40 LOY. L.A. L. REV. 1507 (2006) (analyzing personal jurisdiction in U.S. federal courts in e-commerce cases without paying attention to the location of servers). Little scholarship discusses whether the location of a server can be used as a jurisdiction ground. E.g., Conall O'Reilly, Finding Jurisdiction to Regulate Google and the Internet, 2 EUR. J.L. \& TECH. 1, 3 (2011) (criticizing personal jurisdiction based on the geographic location of a server). 
location of a server to determine personal jurisdiction in internet tort cases, it argues that in the internet era, states have to look for private international law tools to advance their public policy claims about national security and political stability on the internet. ${ }^{4}$ However, the practice shows that the territorial-based jurisdiction rule is limited in fulfilling its legislative goal.

A typical internet tort case generally involves the following servers and other computing equipment. ${ }^{5}$ In some cases, the uploading server and the downloading server may be the same one. ${ }^{6}$
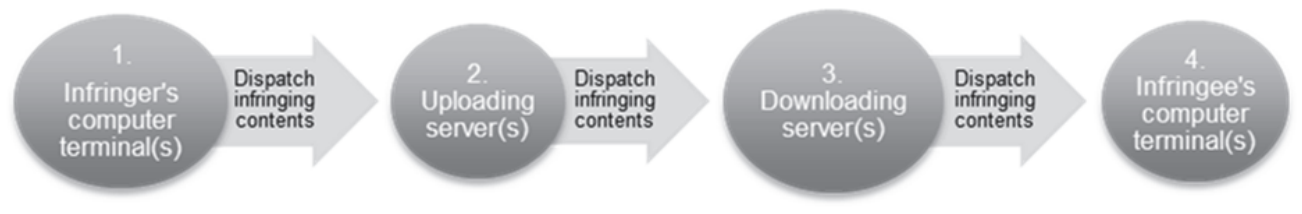

Chart: Servers and other computing equipment involved in a typical internet tort case

\section{Chinese LaW For PERSONAL JURISDiCTION SOLELY BASED ON THE LOCATION OF A SERVER}

Personal jurisdiction based on the location of a server is a territorially-based jurisdiction rule and is "developed in an era when

4 For scholarship emphasizing the private law implications of the geographic location of servers while ignoring their public law significance, see Natascha Bettelheim, Personal Jurisdiction and the Internet: Cyber Differences Shed New Light on Existing Conflicts, 9 J. Internet L. 22, 24 (2006). For scholarship discussing how private international law can go beyond its traditional "private" domain to serve global governance, see Horatia MUIR WATT \& DiEGo P. FERNÁNDEZ ARROYo, PRiVATE INTERNATIONAL LAW AND Global GOVERNANCE 2-19 (2014).

5 Oren Bigos, Jurisdiction over Cross-Border Wrongs on the Internet, 54 INT'L \& COMP. L. Q. 585, 591-92 (2005).

6 In this paper, "uploading" and "downloading" can be defined as follows: "[t]he originator of a document wishing to make it available on the World Wide Web arranges for it to be placed in a storage area managed by a web server. This process is conventionally referred to as 'uploading'. A person wishing to have access to that document must issue a request to the relevant server nominating the location of the web page identified by its 'uniform resource locator (URL)'. When the server delivers the document in response to the request the process is conventionally referred to as 'downloading.". Dow Jones \& Co. v Gutnick (2002) 210 CLR 575, 597-98 (Austl.). 
physical geography was more consequential than it is today." "The development of the internet should have challenged the paradigm of territoriality of law. However, in recent years China has strengthened, rather than weakened, the territorially-based jurisdiction rule. Chinese law permits Chinese courts to exercise personal jurisdiction solely based on the place of the server in internet tort cases in the following two broad scenarios.

First, a court can exercise jurisdiction over a non-resident defendant if it is located in the place where the server that was used for committing the alleged tort is situated. Since 2000, Chinese law has explicitly provided that the Intermediate People's Courts located in the place of infringement or the place of the defendant's domicile shall have jurisdiction over online copyright infringement cases. ${ }^{8}$ The place of infringement includes where the network server, computer terminal or any other equipment used for committing the alleged infringement is located (namely 1, 2 and 3 of the Chart). ${ }^{9}$ Chinese Civil Procedure Law ${ }^{10}$ and SPC Judicial Interpretation Regarding Chinese Civil Procedure Law (hereinafter "2015 Judicial Interpretation of Civil Procedure Law") 11 extend this jurisdiction ground to all internet tort cases. Article 28 of

7 Georgios I. Zekos, Cyber Versus Conventional Personal Jurisdiction, 18 J. INTERNET L. 3, 7 (2015).

8 Interpretation of the Supreme People's Court on Several Issues Concerning the Application of Law in the Trial of Cases Involving Copyright Disputes over Computer Networks (promulgated by the Sup. People's Ct., Nov. 22, 2000, effective Dec. 8, 2006) CLI.3.82171(EN) (Lawinfochina.com), art.1 [hereinafter SPC on Copyright Disputes over Computer Networks]; Interpretation of the Supreme People's Court on Several Issues Concerning the Application of Law in Hearing Civil Dispute Cases Involving Infringement of the Right of Dissemination on Information Networks (promulgated by the Sup. People's Ct., Dec. 17, 2012, effective Jan. 1, 2013) CLI.3.191740(EN) (Lawinfochina.com), art. 15 [hereinafter SPC on Infringement of the Right of Dissemination]; Interpretation of the Supreme People's Court on Several Issues Concerning the Application of Law in the Trial of Cases involving Civil Disputes over Infringements upon Personal Rights and Interests through Information Networks (promulgated by the Sup. People's Ct., Aug. 21, 2014, effective Oct. 10, 2014) CLI.3.235297(EN) (Lawinfochina.com), art. 2 [hereinafter SPC on Infringements upon Personal Rights and Interests through Information Networks].

9 SPC on Copyright Disputes over Computer Networks, supra note 8, art. 1; SPC Provisions on Infringement of the Right of Dissemination, supra note 8 , art. 15; SPC on Infringements upon Personal Rights and Interests through Information Networks, supra note 8, art. 15.

10 Minshi Susong Fa (民事诉公法) [Civil Procedure Law of China] (promulgated by the Standing Comm. Nat'l People's Cong., Apr. 9, 1991, revised June 27, 2017, effective July 1, 2017) CLI.1.297379(EN) (Lawinfochina.com).

11 Interpretation of the Supreme People's Court on the Application of the Civil Procedure Law of the People's Republic of China (promulgated by the Sup. People's Ct., Jan. 20, 2015, effective Feb. 4, 2015) CLI.3.242703(EN) (Lawinfochina.com) [hereinafter 2015 Judicial Interpretation of Civil Procedure Law]. 
Chinese Civil Procedure Law provides that the Intermediate People's Courts located at the place where the tort occurs or at the place of the defendant's domicile shall have jurisdiction over an action instituted for the tort. This provision is clarified by Articles 24 and 25 of the 2015 Judicial Interpretation of Civil Procedure Law. ${ }^{12}$ Article 24 provides that "the place where the tort occurs" includes where the tort activity is committed and where the result of the tort occurs. ${ }^{13}$ Article 25 indicates that in cases where the tort occurs over the internet, the place where a tort activity is committed includes the place where the computers and other information equipment used to commit the alleged tort are located, and the place where the result of the tort occurs. ${ }^{14}$ The latter includes the place where the victim is domiciled. ${ }^{15}$

For example, in Jizhou Aoke Zhongyi Petroleum Co. v. Hensui Yike Fuhe Cailiao Co. Ltd, the plaintiff alleged that the defendant offered to sell products that infringed its patent right on the defendant's website. ${ }^{16}$ The defendant was a company registered in Hebei Province but the server of its website was located in Beijing. ${ }^{17}$ The plaintiff brought the case to the Beijing IP court and the defendant challenged the jurisdiction. ${ }^{18}$ The Beijing IP court held that it had jurisdiction because Chinese Patent Law provides that the place where the patent infringement is committed includes the place of the offer to sell. ${ }^{19}$ The defendant offered to sell the products on its website, and the place of the server could be considered the place where the patent infringement was committed. ${ }^{20}$ The server was located in Beijing, so the Beijing IP court had jurisdiction. ${ }^{21}$ The judgment was affirmed by the Beijing High Court. $^{22}$

Id. arts. 24-25.

13 Id. art. 24.

14 Id. art. 25.

15 Id.

16 Jizhou Ao Ke Zhongvi Shivou Shebei Youxian Gongsi, Hengshui Shi Yi Ke Fuhe Cailiao Youxian Gongsi Qinhai Faming Zhuanli Quan Jiufen An (冀州澳科中意石油设备有限公司、 衡水市艺科复合材料有限公司侵害发明专利权纠纷案) [Jizhou Aoke Zhongyi Petroleum Co. v. Hensui Yike Fuhe Cailiao Co.], Jing Min XIA Zhong No. 317 (Beijing High People's Ct. Aug. 5, 2017) (China).

${ }^{17} I d$.

$18 I d$.

$19 I d$.

${ }^{20} \mathrm{Id}$.

${ }^{21} \mathrm{Id}$.

22 Id. 
Second, in circumstances prescribed by law, if the computer or other equipment that an infringee discovers the infringing contents is located within a court's territorial jurisdiction, this court can exercise personal jurisdiction over the non-resident infringer. Article 2 of the Supreme People's Court (hereinafter "SPC") Judicial Interpretation Regarding Applicable Laws to Civil Cases Related to Computer Domain Name Disputes provides that if the place where the infringement occurs and the defendant's domicile are difficult to identify, the place where the computer or other equipment that the infringee discovers the infringing domain name can be considered the place where the infringement occurs. ${ }^{23}$ The SPC on Copyright Disputes on Computer Networks employed a similar approach. ${ }^{24}$ The SPC Provisions on Infringement of the Right of Dissemination, which replaced the SPC on Copyright Disputes on Computer Networks in 2012, expands this approach. ${ }^{25}$ It stipulates that where both the place of infringement and the defendant's domicile are either difficult to identify or located outside of China, the place where the computer or other equipment on which the infringee discovers the infringing contents is located may also be considered the place where the infringement occurs. ${ }^{26}$ This expansion aims to facilitate domestic plaintiffs with the ability to litigate against foreign defendants in China. "The computer terminal and other equipment where the infringee discovers the infringing contents" may have two interpretations. First is that this equipment is owned by the infringer or a third-party that provides computing service to the infringer (namely, 1, 2, 3 of the Chart). The infringee discovers that this equipment contains infringing contents. The second interpretation is that the equipment belongs to the infringee and by which the infringee discovers the infringing contents (namely, 4 of the Chart). Chinese law does not explicitly require the equipment belonging to the infringee should be in

23 Interpretation of the Supreme People's Court on the Application of Laws in the Trial of Civil Disputes over Domain Names of Computer Networks (promulgated by the Sup. People's Ct., June 26, 2001, effective July 24, 2001), art. 2 [hereinafter SPC on Computer Domain Name Disputes].

24 SPC on Copyright Disputes over Computer Networks, supra note 8, art. 1.

${ }_{25}$ SPC on Infringement of the Right of Dissemination, supra note 8, arts. 3, 15. Article 3 provides that infringement of the right of dissemination refers to the cases where a network user or network service provider provides, on an information network, any work, performance, or audio or video recording which a right holder enjoys the right to disseminate on information networks without the permission of the copyright holder. Id.

26 Id. art. 15 
the infringee's domicile ${ }^{27}$ or the place where the infringement is targeted. This means that the infringee may manipulate personal jurisdiction by simply moving his or her downloading server or computer to the most favorable forum. Consequently, a court which has no connection at all with the subject matter of the dispute may have jurisdiction.

In Mai Jia v. Apple Inc. and iTunes S. a. r. l., Mai Jia was a Chinese resident, while Apple was domiciled in California and iTunes in Luxembourg. ${ }^{28}$ On January 17, 2012, Mai's attorney, accompanied by a notary public, bought an iPod touch in Beijing. ${ }^{29} \mathrm{He}$ used the iPod touch to open the App Store website, where he paid for and downloaded novels and TV series that were written by Mai, but illegally uploaded to the App Store. ${ }^{30}$ The payment receipt indicated "iTunes USD Luxembourg LUX." ${ }^{31}$ After the downloads completed, the notary public encased the iPod touch. ${ }^{32}$ Later, Mai brought a copyright infringement action against Apple and iTunes at the No. 2 Intermediate People's Court in Beijing and submitted the iPod touch as evidence. ${ }^{33}$ Based upon the SPC Provisions on Infringement of the Right of Dissemination, the Court exercised jurisdiction. ${ }^{34}$ The Court ruled that Apple and iTunes infringed Mai's right to disseminate his work online, ordered them to pay damages and to delete the pirated novels and TV series from the App Store. ${ }^{35}$ The cause of action of this case came from a trap purchase conducted by Mai's attorney in Beijing. The total cost for this trap purchase was CNY 30,423. ${ }^{36}$ Besides this cost, Mai requested the two defendants compensate him CNY 1,290,000 for loss of profits. ${ }^{37}$ The court considered the originality and market value of Mai's work, as well as the defendants' infringing activities and negligence, and awarded CNY 200,000 as profit

27 Article 25 of the 2015 Judicial Interpretation of Chinese Civil Procedure Law provides that the place where the result of the tort occurs includes the plaintiff domicile.

28 Maijia Yu Apple Inc. Qinhai Zuopin Xinxi Wangluo Chuanbo Quan Jiufen An (麦家与苹果公司侵害作品信息网络传播权纠纷案) [Mai Jai v. Apple Inc. and iTunes S.a.r.l.], ER ZHONG Min CHU Zi No. 5279 (Beijing Interm. People's Ct. Apr. 23, 2013) (China).

${ }^{29}$ Id.

30 Id.

31 Id.

32 Id.

33 Id.

34 Id.

${ }^{35} I d$.

$36 \quad I d$.

${ }^{37} \mathrm{Id}$. 
loss and CNY 5,000 as reasonable litigation costs. ${ }^{38}$ The court did not explain how CNY 200,000 was calculated in detail. ${ }^{39}$ Since this amount clearly went beyond the cost of the trap purchase, it may be considered an award for damages that Mai suffered from the defendants' infringement throughout China other than the trap purchase. ${ }^{40}$ In this case, as long as the infringee could use a piece of equipment to browse the App Store in Beijing, the Beijing court could exercise its jurisdiction and award damages throughout China.

The judgment of Sunny Co. v. Taobao Co. provides legislative reasoning as to why Chinese courts can exercise personal jurisdiction in the above two scenarios. ${ }^{41}$ First, the infringer connects his computer or other terminals with a server and undertakes upload, download, and dissemination activities. ${ }^{42}$ The terminal is a necessary tool for the infringer to commit the infringement because he sends his "infringement order" from the terminal. ${ }^{43}$ When the order reaches the internet server, online infringement occurs. ${ }^{44}$ Therefore, the terminal and the server are essential to the infringement, and the location of the terminal or the server is where the online tort is committed ${ }^{45}$ So, 1,2 , and 3 of the Chart can be considered the place where the tort occurs. Second, 4 of the Chart should be considered the place where the result of a tort occurs, so the court in this place has jurisdiction. Third, the court at the place that is in the same location as the server has proximity to collect evidence and enforce judgments by deleting infringing contents from the server. ${ }^{46}$

Should 1, 2, 3, or 4 of the Chart be considered the place where an internet tort occurs? To facilitate our discussion, this paper divides servers into three groups: the infringer's server (Part II), the server that belongs to a third party contracting with the infringer (Part III), and the

38 Id.

39 Id.

40 Id.

41 Suning Yunshang Jituan Gufen Youxian Gongsi Yu Zhejiang Taobao Wangluo Youxian Gongshi Qinhai Shangbiaoquan Jiufen An (苏宁云商集团股份有限公司与浙江淘宝网络有限 公司侵害商标权纠纷案) [Sunny Co. v. Taobao Co.], Ning ZHI MiN XIA ZHONG Zi No. 7 (Nanjing Interm. People's Ct. May 27, 2014) (China).

42 Id.

43 Id.

44 Id.

45 Id.

46 This is significant to achieve global removal, blocking, or delisting of the infringing content from the internet. See Dan Jerker B. Svantesson, Jurisdiction in 3D-"Scope of (Remedial) Jurisdiction” as a Third Dimension of Jurisdiction, 12 J. PRIV. INT’L L. 60, 63 (2016). 
infringee's server (Part IV). It contrasts Chinese law with laws in the U.S., Australia, and the EU. It also analyzes this question in the context of the new digital economy (e.g., domain name, outsourcing, cloud computing, and platform). It concludes that without the "directed" factors, the location of a server should not be considered the place where the online tort occurs. The exceptions include illegal transmission of emails and domain name disputes. Then, it returns to China's national condition and explores the public law reasons for this territorial-based personal jurisdiction rule (Part V). It concludes that this jurisdiction rule cannot fulfill its legislative reasons and advances a proposal to improve this personal jurisdiction rule (Part VI and VII).

\section{INFRINGER'S SERVER}

Torts occurring over the internet are not an issue only for China. Courts in other countries have also been called upon to answer the question of whether a server's location is where the tort occurs. Compared with the third-party server and the infringee's server, the infringer's server is most often proposed as the place where the tort occurs. It is worthwhile to examine how courts in the U.S., EU, and Australia decide this issue.

U.S. courts can exercise either specific or general jurisdiction over a non-resident defendant. ${ }^{47}$ The traditional test establishing specific personal jurisdiction over a non-resident defendant has three prongs. ${ }^{48}$ First, the defendant must come within the terms of the applicable state long-arm statute. ${ }^{49}$ Second, the defendant must have minimal contacts with the forum state, such that the assertion of jurisdiction would not violate the Due Process Clause. ${ }^{50}$ This requires the defendant to have purposely availed itself of the privilege of conducting activities in the

47 If a defendant is engaged in "continuous and systematic" activity in the forum state, U.S. courts can exercise general jurisdiction regardless of the cause of action. Helicopteros Nacionales de Colom., S.A. v. Hall, 466 U.S. 408, 415 (1984). This paper will focus on specific jurisdiction because it is more frequently used in cases involving non-resident defendants.

48 Int'l Shoe Co. v. Washington, 326 U.S. 310, 316 (1945); World-Wide Volkswagen Corp. v. Woodson, 444 U.S. 286, 291-92 (1980); Asahi Metal Indus. Co. v. Superior Court, 480 U.S. 102, 108-09 (1987).

49 Burke T. Ward, Where in the World is Internet Jurisdiction: A U.S. Perspective, 4 INT'L J. VALue Chain MGMT. 5, 7-9 (2010).

50 Richard L. Garnett, Trademarks and the Internet: Resolution of International IP Disputes by Unilateral Application of U.S. Laws, 30 BROOK. J. INT’L L. 925, 930 (2005). 
forum state ${ }^{51}$ The lawsuit must also either arise out of or be related to the defendant's purposeful contacts with the forum or the defendant's forum contacts are so extensive that no such relationship is necessary. ${ }^{52}$ Finally, the exercise of jurisdiction must be fair and reasonable. ${ }^{53}$ In the internet era, most U.S. courts still follow this three-prong test, but with two different approaches to determining sufficient minimum contacts with the forum state. ${ }^{54}$ However, neither of the two approaches allows personal jurisdiction based solely on the geographic location of a server.

The first approach comes from the seminal defamation case, Calder v. Jones. ${ }^{55}$ The Calder effects test provides that a forum has personal jurisdiction over a non-resident defendant who committed an intentional act, expressly aimed at the forum state, knowing that harm is likely to be suffered in the forum state. ${ }^{56}$ Penguin Group (USA) Inc. $v$. American Buddha clarifies whether, in online copyright infringement cases, the situs of injury for the relevant New York law $^{57}$ is the location of the infringing action (e.g., copying and uploading contents online) or the principal place of business of the copyright holder. ${ }^{58}$ American Buddha was accused of copyright infringement by Penguin Group (USA) Inc. ${ }^{59}$ American Buddha argued that the copying and uploading of the books took place in either Oregon or Arizona, where its servers were located. ${ }^{60}$ The Southern District of New York held that the situs of injury was where the copying and uploading of the books took place. ${ }^{61}$ This decision was reversed by the appellate court, which held that in the context of the internet, it was "illogical" to equate a plaintiff's injury in

${ }^{51} I d$.

52 Id.

53 Sheldon Burshtein, Jurisdiction in Internet Trade-Mark and Domain Name Disputes, 20 INTELL. PROP. J. 1, 7-9 (2006).

54 See Yasmin R. Tavakoli \& David R. Yohannan, Personal Jurisdiction in Cyberspace: Where Does it Begin, and Where Does it End?, 23 INTELL. Prop. TECH. L.J. 3, 3 (2011).

55 Calder v. Jones, 465 U.S. 783 (1984). In this case, Jones resided in California and her television career was centered there; the allegedly libelous article was written and edited by an editor and a writer residing in Florida with few contacts with California; the article was drawn from California sources; and the magazine had its largest circulation in California. Id. The U.S. Supreme Court held that "California is the focal point both of the story and of the harm suffered," so based on the "effects" of the defendants' Florida conduct in California, California could exercise personal jurisdiction over them. Id. at 789 .

56 Id. at 788-89.

57 N.Y. Civil Practice LaW \& Rules 302 (a)(3)(ii) (McKinney 2018).

58 Penguin Grp. (USA) Inc. v. Am. Buddha, 16 N.Y.3d 295, 301-02 (N.Y. 2011).

$59 I d$. at 300 .

${ }^{60} \mathrm{Id}$.

${ }^{61} I d$. at 305 . 
an online copyright infringement case with the place where the content was uploaded. ${ }^{62}$ The appellate court emphasized that its decision did not open Pandora's box in allowing New York courts to exercise personal jurisdiction over any non-resident accused of online copyright infringement because of a safeguard in the New York law that incorporates the Calder effects test: the non-resident "expect[s] or should reasonably expect the act to have consequences in the state and derives revenue from interstate or international commerce." ${ }^{63}$ In other words, the state where a non-resident's server is located is not the place where the tort occurs, except that the defendant expressly aimed at that state and expects the harm is likely to be suffered in that state.

The second approach is the Zippo Sliding Scale Test. In Zippo Manufacturing Co. v. Zippo Dot Com, Inc. ${ }^{64}$ the plaintiff, a Pennsylvania company manufacturing cigarette lighters, filed suit alleging trademark dilution against the defendant, an online news provider located in California. The defendant operated three websites under the name of Zippo: Zippo.com, Zippo.net and Zipponews.com. ${ }^{65}$ Their servers were all located in California. ${ }^{66}$ Only 2 percent of defendant's customers were Pennsylvania residents. ${ }^{67}$ The defendant contracted with seven internet access providers in Pennsylvania to permit their subscribers to access its online news service. ${ }^{68}$ The court used a sliding scale test to determine whether it was proper to exercise jurisdiction. At one end of the sliding scale are active websites where a non-resident defendant clearly conducts business over the internet. ${ }^{69}$ For example, the defendant enters into contracts with residents of a forum jurisdiction that involves the knowing and repeated transmission of computer files over the internet. In such a case, the forum can exercise personal jurisdiction over the defendant. At the other end of the scale are passive websites where a foreign defendant has simply posted information on the internet which is accessible to users in the forum jurisdiction, and the forum cannot exercise personal jurisdiction..$^{70}$ The middle of the scale consists of interactive websites

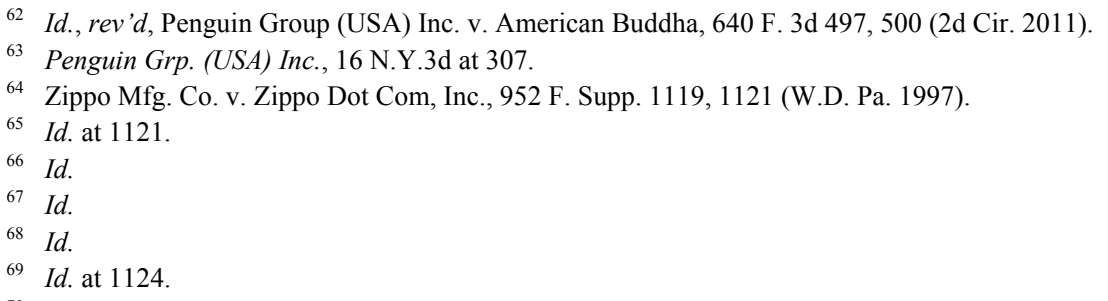


where a user can exchange information with the host computer. The exercise of jurisdiction is based on the level of interactivity and commercial nature of the exchange of information on the website. ${ }^{71}$ The court in Zippo held that the defendant's website was an active website because it offered three levels of memberships (public/free, original, and super) to subscribers and charged fees for news provided online. ${ }^{72}$ Therefore, Pennsylvania had jurisdiction. ${ }^{73}$ The Zippo sliding scale test focuses on the interactive service that a website can provide rather than where the infringer's server or other computing equipment is physically located. Following Zippo, in American Eyewear, Inc. v. Peeper's Sunglasses and Accessories Inc., the court found the fact that Peeper's host computers were not located in Texas and its sales to Texas residents constituted fewer than one-half of one percent of its total sales were irrelevant to whether personal jurisdiction could be exercised. ${ }^{74}$

In Australia, the location of an infringer's servers and other computing equipment (namely 1, 2, and 3 of the Chart) also appears to be irrelevant to personal jurisdiction. For example, in Dow Jones \& Company Inc $v$ Gutnick, ${ }^{75}$ the High Court of Australia held that material published online was not available in comprehensible form until downloaded onto the computer of a person who has used a web browser to pull the material from the server, and that the place from which the harmful conduct was committed was where that person downloaded the material. $^{76}$

Cooper v Universal Music Australia Pty Ltd is a case in which an Australian copyright holder successfully claimed copyright infringement against an MP3-sharing website owned by Cooper, even though the website was independent of the servers that actually hosted the MP3 files. ${ }^{77}$ When an internet user clicked on a particular hyperlink on the Cooper website, the music file in question was transmitted directly to his or her computer from a remote server. The "Disclaimer" on the website provided that "[w]hen you download a song, you take full responsibility for doing so. None of the files on this site are stored on our

${ }^{71}$ Id.

72 Id. at $1125-27$.

73 Id.

74 Am. Eyewear, Inc. v. Peeper's Sunglasses \& Accessories, Inc., 106 F. Supp. 2d 895, 902-03 (N.D. Tex. 2000).

75 Dow Jones \& Co v Gutnick (2002) 210 CLR 575 (Austl.).

76 Id. 44.

77 Cooperv Universal Music Austl Pty Ltd (2006) 237 ALR 714 (Austl). 
servers. We are just providing links to remote files ... We are not responsible for any damage caused by downloading these files. . . " 78 The judge held that it was immaterial that the music subject to copyright was not stored on the Cooper website or the host server of the Copper website. ${ }^{79}$

Similarly, in Ward Group Pty Ltd v Brodie \& Stone PLC, an online trademark infringement case, the court found that if online publications or statements were made to the world generally rather than to a particular jurisdiction, it may be difficult to regard them as having been made by a website in a particular jurisdiction, but if the publications or statements are directed or targeted at persons or subscribers in a particular jurisdiction, they are considered to be made and received in that jurisdiction. ${ }^{80}$ Therefore, places of 1,2 , and 3 of the Chart will not be considered the place where the tort occurs (the place where the tort is committed or the place where the injury occurs).

In the EU, personal jurisdiction related to tort, delict, or quasidelict is regulated by Article 7(2) of Brussels I Regulation on Jurisdiction and the Recognition and Enforcement of Judgments in Civil and Commercial Matters (Recast). ${ }^{81}$ It provides that the domestic courts where the harmful event has occurred or may occur have jurisdiction. ${ }^{82}$ The place where the harmful event has occurred or may occur includes where the damage has occurred or may occur and the place of the event giving rise to the damage. ${ }^{83}$ The European Court of Justice ("ECJ") case law shows that 1,2 , and 3 of the Chart are not considered the place where the harmful event occurred or may occur. ${ }^{84}$ For example, Football Dataco Ltd v. Sportradar GmbH explicitly forbids courts to exercise

$78 \quad I d .9100$.

$79 \quad I d .943$.

${ }^{80}$ Ward Grp Pty Ltd v Brodie \& Stone PLC (2005) 215 ALR 716, 728 (Austl.). See also 101 Domain Inc v BB Online UK Ltd (2014) 110 IPR 650, 656 (Austl.).

81 Regulation (EU) No. 1215/2015 of European Parliament and of Council of 12 December 2012 on Jurisdiction and the Recognition and Enforcement of Judgments in Civil and Commercial Matters, art. 7, 2012 O.J (L 351) 1, 2.

82 For detailed analysis of Article 5(3) of Brussels I Regulation, see Sophie Neumann, Intellectual Property Rights Infringements in European Private International Law: Meeting the Requirements of Territoriality and Private International Law, 7 J. PRIV. INT'L L. 583, 591-95 (2011).

83 Case 21/76, Handelskwekerij GJ Bier BV v. Mines de Potasse d'Alsace SA, 1976 E.C.R. 1735; James J. Fawcett \& Paul Torremans, Intellectual Property And Private INTERNATIONAL LAW 153-75 (2d ed. 2011).

${ }^{84}$ E.g., Case C-173/11, Football Dataco Ltd v. Sportradar GmbH (Oct. 18, 2012), http://curia. europa.eu/juris/liste.jsf?num $=\mathrm{C}-173 / 11 \&$ language $=\mathrm{EN}$. 
personal jurisdiction based upon the geographic location of servers and the infringer's computing equipment (namely 1, 2 and 3 of the Chart).$^{85}$ This case is concerned with database right (sui generis right) infringement. ${ }^{86}$ Football Dataco Ltd. ("Dataco") compiled and marketed live data from English and Scottish Premier League football matches (e.g., goals, goal scorers, yellow cards, etc.) in its "Football Live" database. Sportradar GmbH ("Sportradar") was a German company that provided data related to sports events, including English football matches, via its website to its clients, which included a UK-based betting company ${ }^{87}$ Dataco brought a claim against Sportradar before the UK High Court alleging infringement of its database rights by Sportradar's unauthorized use of its "Football Live" database. ${ }^{88}$ Sportradar argued that the High Court had no jurisdiction to hear the case because Sportradar's data was stored on servers that were located in Germany and Austria and liability for infringing acts could only arise in the jurisdiction from which the data was sent (i.e., Germany/Austria) and not where it was received (e.g., by members of the public in England). ${ }^{89}$ The ECJ rejected this argument. ${ }^{90}$ It held that the infringement took place at least in the Member State where the person who requested and then received the data was located, provided that there was evidence that the person sending the data intended to target members of the public in that Member State. ${ }^{91}$ The ECJ held that the UK court had jurisdiction for three reasons. ${ }^{92}$

First, the subject matter of the data could have been of particular interest to members of the public in the UK because data on Sportradar's server related to English and Scottish football league matches, which shows Sportradar's intention to attract members of the public in the UK. ${ }^{93}$ Second, it was known by Sportradar's website operator that its data is likely to be accessed by members of the public in the UK. ${ }^{94}$ Sportradar's customers included a UK-based betting agency, which

\footnotetext{
$85 I d$.

86 Id. $\llbracket 2$.

87 Id. 910.

88 Id. ๆศ 8, 11.

${ }^{89}$ Id. १ๆ $15-16$.

90 Id. 9 ๆ $38-47$.

91 Id. बा 45-47

92 Id. १ศ $38-42$.

93 Id.

94 Id. $ๆ 40$.
} 
shows Sportradar's awareness that end-users accessing its data could be from the UK. ${ }^{95}$ Third, although Sportradar is a German company, it provides access to its football data in English. ${ }^{96}$ This also suggests Sportradar's intention to target a particular member state.

In addition, Article 2:202 of the European Max Planck Group on Conflict of Laws in Intellectual Property ("Max Planck Principles") provides that "[i]n disputes concerned with infringement of an intellectual property right, a person may be sued in the courts of the state where the alleged infringement occurs or may occur, unless the alleged infringer has not acted in that State to initiate or further the infringement and her/his activity cannot reasonably be seen as having been directed to that State." ${ }^{\prime \prime 7}$ Although the state where an infringer's server is located might be considered the place where the alleged infringement occurs or may occur, the court in that state cannot exercise jurisdiction over a nonresident infringer unless the infringement is directed at that state.

As a conclusion, different from Chinese law, jurisprudence from the U.S., Australia, and EU shows that the location of a server should be combined with the "directed" factors, which means the non-resident defendant must directly target its website at the forum state by knowingly interacting with residents of the forum state via its website or through sufficient other contacts. ${ }^{98}$ The mere location of the infringer's server should not be considered the place where the tort occurs. Compared with the Chinese approach prioritizing geographic location, the approach requiring the "directed" factors may better fit with the reality of the internet for three reasons.

First, internet torts may differ from atmospheric or water pollution in that the origin of the damage is located in a different state than where the harm itself occurs. Handelskwekerij G. J. Bier B.V. v. Mines de Potasse d'Alsace S.A. is a typical water pollution case, where the defendant's mine polluted water in the Rhine in France and the Dutch plaintiff suffered the harm in the downstream Rhine. ${ }^{99}$ Internet tort is

95 Id. 941.

$96 \quad I d .942$.

97 Max Planck Group on Conflict of Laws in Intellectual Property, Principles for CONFLICTS OF LAWS IN INTELLECTUAL PROPERTY, art. 2:202 (Dec. 1, 2011) (emphasis added).

98 Venture Tape Corp. v. McGills Glass Warehouse, 292 F. Supp. 2d 230, 233 (D. Mass. 2003). The Venture Tape Corp. court held that the defendant "should anticipate being hauled into court in Massachusetts" because "the target of the alleged trademark infringement was a Massachusetts company." Id.

99 Case 21/76, Handelskwekerij GJ Bier BV v. Mines de Potasse d'Alsace SA, 1976 E.C.R. 1735, $1736-37$. 
different from water pollution in two aspects. First, suppose that a French company uploads defaming information of a Dutch celebrity on a server located in France. The online defamation and the water pollution both involve physical equipment: the former is the server and the latter is the mine. However, in the internet tort, the editing and uploading defamation information on the French server will not constitute a tort unless the audience read the information. The audience is in the Netherlands. Therefore, the location of the server is not the place where the tort occurs. Nevertheless, in the water pollution case, the mine pollutes water in the Rhine River, including the part in France. The result of pollution also occurs in France regardless of whether the plaintiff claims it or not. ${ }^{100}$ The place of the mine is where the tort occurs. Therefore, the location of the equipment has significance in water pollution, but not in the internet tort. The second reason an internet tort is different is that, in water pollution, courts do not consider the "directed" factors, because the pollution is ubiquitous. In contrast, the internet is ubiquitous, but internet tort is not, unless the infringer directs the tort at the world at large. Courts consider "directed" factors when deciding jurisdiction as demonstrated by the Calder effect test, the interactive website in the Zippo test, and the holdings in Dow Jones and Football Dataco Ltd. ${ }^{101}$

Second, a server that saves infringing contents is different from a brick-and-mortar warehouse that stores infringing commodities. The courts located in the place where large quantities of infringing commodities are stored or hidden, or infringing commodities are regularly stored or hidden should have jurisdiction over trademark infringement cases. ${ }^{102}$ This does not necessarily mean a court located in the same place as a server that saves infringing contents should have jurisdiction. For internet tort, it is not the physical location of the server that is relevant but "rather the network address, internet provider address and the URL address associated with the computers."

\footnotetext{
${ }^{100} I d$. at 1744-48. In Handelskwekerij GJ Bier BV, the plaintiff only claimed the pollution in the Netherlands.

${ }^{101}$ Calder v. Jones, 467 U.S. 752, 768 (1984); Zippo Manufacturing Co. v. Zippo Dot Com, Inc., 952 F. Supp. 1119, 1124 (W.D. Pa. 1997); Dow Jones \& Co Inc v Gutnick (2002) 210 CLR 575, 597-598 (Austl.); Case C-173/11, Football Dataco Ltd. v. Sportradar GmbH, (Oct. 18, 2012), http://curia.europa.eu/juris/liste.jsf?num=C-173/11\&language=EN.

${ }^{102}$ Interpretation of the Supreme People's Court Concerning the Application of Laws in the Trial of Cases of Civil Disputes Arising from Trademarks (promulgated by the Sup. People's Ct., Oct. 12, 2002, effective Oct. 16, 2002) CLI.3.42739(EN) (Lawinfochina.com), art. 6 [hereinafter SPC on Civil Disputes Arising from Trademarks].

${ }^{103}$ Universal Music Austl Pty Ltd v Cooper, [2005] FCA 972 (14 July 2005) ๆ 23 (Austl.).
} 
addresses are digital rather than physical. In practice, 1, 2, and 3 of the Chart may not be in the place where the infringing activities are directed. This is because the infringer may select the location of its server based on criteria unrelated to the infringing activities, such as the cost, space, speed, and security of the server, as well as the convenience and data freedom offered in the state where it is located. ${ }^{104} \mathrm{~A}$ server can be located thousands of miles away from the place where the infringing activities are directed. The long distance has no impact on the gravity of the infringement. In contrast, in trademark infringement cases, the brick-andmortar warehouse that stores or regularly stores large quantities of infringing commodities is closely related to the infringement. This is because the brick-and-mortar warehouse is generally geographically located either close to the place of manufacture or the place of sale, for the benefits of easy transportation. This is significantly distinguished from online tort where an infringer may purposefully select a server located far away from the place where the infringing activity is directed. Geographic distance has impacts on traditional tort, but has no significance on online tort. Therefore, the place where the server is located is not related to the place where the tort occurs. It is unreasonable to hale an infringer into a court or require a victim to litigate in a court merely because the infringer's server is located there unless the infringer's activity targets that forum state.

Third, if the court at the place of the server can exercise personal jurisdiction merely because of the location, it may encourage forum shopping. For example, a party may deploy its server in a state with the most favorable law for it. In case of IP dispute cases, the party may initiate an action in one state for an affirmation that it does not commit any infringement.

\section{THIRD-PARTY SERVER}

The development of digital technology and pursuit of benefits such as big data insights encourage internet traders to use third-party servers to conduct their business. ${ }^{105}$ If an infringer uses a third-party server to commit an internet tort, should the location of the server be

104 James Fawcett et al., InTERnational SALE of Goods in the Conflict of Laws 1306 (2005).

${ }^{105}$ Stephanie Overby, How Digital Transformation Is Disrupting IT Outsourcing, CIO.COM (Oct. 9, 2015, 4:58 AM), https://www.cio.com/article/2991281/outsourcing/how-digital-transformationis-disrupting-it-outsourcing.html. 
considered the place where the tort occurs? The arguments in Part II apply. Meanwhile, we need to consider specialties of third-party servers. This section explores the typical examples of third-party servers: domain name registration, outsourcing, platform and network supplier.

\section{A. DOMAIN NAME REgISTRATION}

A domain name is registered on a third-party (i.e., registrar) server. Suppose that a plaintiff alleges his or her trademark is illegally registered as the defendant's domain name, could the plaintiff bring the case in the place where the domain name is registered instead of the defendant's domicile? In other words, can the place where the domain name is registered be considered the location where the tort occurs? The answer is yes. For example, Rules for Uniform Domain Name Dispute Resolution Policy provide that domain name disputes can be heard in court "at the location of the principal office of the Registrar (provided the domain-name holder has submitted in its Registration Agreement to that jurisdiction for court adjudication of disputes concerning or arising from the use of the domain name)." ${ }^{106}$

Chinese law provides the same answer. ${ }^{107}$ For example, in Qinhuangdao Hongshun Co. v. Thailand TRUE Co., the court held that the place where the disputed domain name is registered is the place where the tort activity is conducted. ${ }^{108}$ Hongshun Co. was domiciled in Qinhuandao, Hebei Province, while TRUE was a Thai company. Hongshun sued TRUE in an Intermediate Court in Xiamen, Fujian Province, requesting the Court to affirm Hongsun's domain name did not infringe TURE's trademark. ${ }^{109}$ The company that registered Hongsun's domain name was domiciled in Xiamen, which was the only base for the Xiamen court to exercise jurisdiction. ${ }^{110}$ TRUE appealed to the Higher People's Court of Fujian Province, arguing that the intermediate court

\footnotetext{
${ }^{106}$ Rules for Uniform Domain Name Dispute Resolution Policy, ICANN (Sept. 28, 2013), https:// www.icann.org/resources/pages/udrp-rules-2015-03-11-en. The other available court is the court "at the domain-name holder's address as shown for the registration of the domain name in Registrar's Whois database at the time the complaint is submitted to the Provider." Id.

${ }^{107}$ SPC on Computer Domain Name Disputes, supra note 23, art. 2.

${ }^{108}$ Qinhuangdao Hongshun Keji Kaifa Youxian Gongsi Yu Tailand True Co. Ltd Queren Buqinhai Shangbiaoquan Jiufen An (秦皇岛鸿顺科技开发有限公司与泰国TRUE（大众）有限公司确 认不侵害商标权纠纷案) [Hongshun Co. v. Thailand TRUE Co.], MIN MIN ZHONG ZI No. 1511 ${ }^{109} \mathrm{Id}$. (Fujian High People's Ct. Dec. 16, 2014) (China).

${ }_{110}$ Id.
} 
wrongly exercised jurisdiction. ${ }^{111}$ The Higher Court affirmed the Intermediate Court's jurisdiction, holding that the domain name registrar was located and that the tort had occurred in Xiamen, so the Xiamen court had jurisdiction. ${ }^{12}$

The same conclusion was reached in Atomic Energy Commissariat Co. v. Xibao Company. ${ }^{113}$ Atomic Energy Commissariat Co. is a French company and Xibao Co. is domiciled in Xiamen. ${ }^{114}$ Atomic Energy Commissariat alleged that its trademark "AREVA" was illegally registered as a domain name by Xibao. ${ }^{115}$ Because the domain name was registered at the China Internet Information Center, which is located in Beijing, Atomic Energy Commissariat brought the case to an Intermediate Court in Beijing. ${ }^{116}$ Xibao appealed to the Beijing Higher People's Court, arguing that the Intermediate Court wrongly exercised jurisdiction and the case should be tried in Xiamen. ${ }^{117}$ The Higher People's Court affirmed the judgment, holding that Beijing was the place where the tort occurred, so the Intermediate Court had jurisdiction. ${ }^{118}$

In conclusion, in domain name disputes, courts in the place where the domain name is registered have jurisdiction. However, domain name disputes should be distinguished from other internet tort cases (e.g., online defamation and IP disputes), because the registration (tort) occurs on the registrar's server. Notably, courts focus on the registrar's domicile rather than the mere geographic location of the server, though the two locations may often overlap.

\section{B. OUTSOURCING}

Outsourcing of internet service has become a more frequent practice in the modern internet economy. For example, in Australian Competition and Consumer Commission v Valve Corporation (No 3),

\footnotetext{
${ }^{111} I d$.

${ }^{112} I d$.

${ }^{113}$ Yuanzineng Junxubu Konggu Gongsi Yu Xiamen Xibao Keji Youxian Gongsi An (原子能军需 部控股公司与厦门熙保科技有限公司案) [Atomic Energy Commissariat Co. v. Xiamen Xibao Sci. \& Tech. Co.], GaO Min Zhong Zi No. 47 (Beijing Higher People's Ct. Jan. 2008) (China). ${ }^{114} I d$.

${ }^{115}$ Id.; see ORANO, http://us.areva.com/ (last visited Oct. 15, 2018) ("Prior to a global rebranding in January 2018, Orano USA was AREVA Nuclear Materials."); Teddy Areva, Le Blog de Teddy, http://www.areva-td.com/ (last visited Oct. 15, 2018).

${ }^{116} I d$.

${ }^{117} I d$.

${ }^{118} I d$.
} 
like many multinational online companies, Valve, a U.S. company, operated "Stream," an online game distribution network that targeted consumers all over the world. ${ }^{119}$ Valve outsourced part of its internet service to third parties in Australia. ${ }^{120}$ The issue was whether its outsourcing business, combined with other factors, demonstrates it supplied goods or carried on business in Australia, so an Australian court could exercise jurisdiction. ${ }^{121}$ Valve argued that its online representations were not directed to anyone in Australia. ${ }^{122}$ Yet, the Federal Court of Australia concluded that Valve supplied goods in Australia because although the online representations made by Valve were directed to the world at large, when an Australian consumer purchased a game or downloaded Stream Client, the consumer had a relationship with Valve and representations were made in Australia under the Australian Competition and Consumer Act. ${ }^{123}$ Alternatively, Valve also carried on business within Australia under section 5(I)(g) of the Australian Consumer Law $^{124}$ because: (1) Valve had approximately 2.2 million Australian accounts and earned significant revenue from Australia; (2) although Valve had no real property in Australia, it had servers in Australia with a retail value of $\$ 1.2$ million, which were initially configured by an employee who travelled to Australia, and Valve paid to the Australian bank account of an Australian company for equipment involving servers; (3) although the Stream content was not "pre-loaded or stored" on Valve's servers in Australia, it was "deposited" on Valve's three servers in Australia when requested by a subscriber and would stay on the server if it was requested again in a particular period of time; (4) Valve spent a lot money in Australia for the rack space and power to its servers and those expenses were paid by Valve to the Australian bank account of an Australian company; (5) Valve relied on third-party

\footnotetext{
119 Australian Competition \& Consumer Comm'n v Valve Corp (No 3), [2016] FCA 196, $₫ 1$.

${ }^{120}$ Id. ฯा 24, 25, 32, 203.

${ }^{121} I d$. ๆๆ 60, 72, 76, 83, 254.

${ }^{122} I d$. $₫ 165$.

${ }^{123}$ Id. | 181,188 . The court explains that "[t]he purchase of a game also required a consumer to click on a box that agreed to the terms of the Steam Subscriber Agreement. The consumer provided Valve with his or her location as Australia at the time of purchase. Indeed, Valve priced some games differently in Australia ... The consumer might be told by Valve that 'This item is currently unavailable in your region." $I d$.

${ }^{124}$ Competition \& Consumer Act 2010 (Cth) s 5(1)(g) (Austl.) ("Extended application of this Act to conduct outside Australia (1) Each of the following provisions ... extends to the engaging in conduct outside Australia by ... bodies corporate incorporated or carrying on business within Australia...")
} 
content delivery providers in Australia to provide proxy caching for Valve in Australia; and (6) Valve contracted with third-party service providers to provide content online in Australia and other places in the world, and Valve knew that the providers had servers in Australia. ${ }^{125}$ Therefore, the court could exercise jurisdiction over Valve. The court's finding on the complex issue of jurisdiction has implications for all foreign e-commerce companies who often do not have business premises or staff employed in Australia but have servers or contracted with thirdparty service providers who have servers in Australia. Courts consider the outsourcing of third-party servers when determining personal jurisdiction. In this case, the court did not consider the "directed" factor, because the Australian Competition and Consumer Act and the Australian Consumer Law did not require the court to do so.

\section{INFRINGEE'S SERVER}

The second interpretation of "computer terminal and other equipment where the infringee discovers the infringing contents" ${ }^{126}$ is that the plaintiff uses its own equipment to discover the infringing contents (namely, 4 in the Chart). Chinese law does not explicitly require that 4 in the Chart should be the infringee's domicile or the place where the infringement is directed. ${ }^{127}$ This means that the infringee can manipulate personal jurisdiction by simply moving his or her downloading server or computer to the most favorable forum. Consequently, a court that has no connection at all with the subjectmatter of the dispute may have jurisdiction. The "[p]lace where the harmful event occurred" cannot be "construed so extensively as to encompass any place where the adverse consequences can be felt of an event which has already caused damage actually arising elsewhere." ${ }^{\prime 28}$ Therefore, if the computer terminal and other equipment is owned by the plaintiff, they should not be in a fortuitous location. They should be either in the infringee's domicile or the place where the infringement is directed.

\footnotetext{
${ }^{125}$ Valve Corp (No 3), [2016] FCA 196, ฯฯ 198-205.

${ }^{126}$ See supra Part I.

${ }^{127}$ Civil Procedure Law of China, supra note 10, art. 25 (providing that the place where the result of the tort occurs includes the plaintiff domicile).

${ }^{128}$ C-364/93, Marinari v. Lloyds Bank, 1995 E.C.R. I-2733, $\mid 14$.
} 
Nevertheless, illegal transmission of e-mails should be an exception to the above argument. Litigation involving the illegal transmission of e-mails, such as commercial spams, presents a jurisdictional conundrum - whether their purveyors have purposefully availed themselves of the forum state where the server is located-to resolve. ${ }^{129}$ This is because e-mail addresses (e.g., Jack.Chen@gmail.com) indicate the domain name of the server that processes emails but may not release information about the geographical location of the server. In Intercon, Inc. v. Bell Atlantic internet Solutions, ${ }^{130}$ the U.S. Court of Appeals for the Tenth Circuit exercised jurisdiction based upon the location of the infringee's server. Intercon was an Oklahoma corporation operating "icon.net" while Bell Atlantic was a Delaware corporation owning "iconnet.net." 131 A routing error occurred, causing Bell Atlantic to route its customers' emails through Intercon's server instead of its own. ${ }^{132}$ Intercon sued Bell Atlantic in Oklahoma. ${ }^{133}$ The court rejected Bell Atlantic's arguments that its inadvertent contacts with Oklahoma were merely "fortuitous," finding instead that Bell Atlantic's continued use of Intercon's server, after receiving notice of the misrouting problem, was both "knowing and international." 134 In Verizon Online Services, Inc. v. Alan Ralsky, et al., Verizon was a Delaware corporation with its principal place of business in Virginia. ${ }^{135}$ The defendants were residents of Michigan. ${ }^{136}$ Verizon contended that the defendants' alleged transmissions of millions of unsolicited bulk e-mails overwhelmed Verizon's servers causing delays in the processing of legitimate emails and leading to consumer complaints. ${ }^{137}$ The court held that the defendants' transmission of the e-mails constituted sufficient minimum contacts in Virginia because they solicited business from Verizon's subscribers for profits, the transmission through Verizon's servers was intentional with seven of them located in Virginia, and it consumed fiftysix gigabytes of memory on a single day on Verizon's servers. ${ }^{138}$ These

\footnotetext{
${ }^{129}$ Verizon Online Servs., Inc. v. Ralsky, 203 F. Supp. 2d 601, 612 (E.D. Va. 2002).

${ }^{130}$ Intercon, Inc. v. Bell Atlantic Internet Sols., Inc., 205 F.3d 1244 (10th Cir. 2000).

${ }^{131} \mathrm{Id}$. at 1246.

${ }^{132} \mathrm{Id}$.

${ }^{133} \mathrm{Id}$.

${ }^{134} \mathrm{Id}$. at 1248.

${ }^{135}$ Verizon Online Servs., Inc. v Ralsky, 203 F. Supp. 2d 601, 607 (E.D. Va. 2002).

${ }^{136} \mathrm{Id}$.

${ }^{137} \mathrm{Id}$. at 608 .

${ }^{138} I d$. at $615-21$.
} 
cases demonstrate that illegal transmission of e-mails constitutes the tort of trespass to chattel; therefore, personal jurisdiction can be exercised based on the location of the infringee's server.

\section{LEGISLATIVE REASONS FOR JURISDICTION BASED ON THE LOCATION OF A SERVER}

The internet is an amorphous space, but the location of the server can be physically and geographically anchored, equalizing state territoriality with cyberspace sovereignty. State legislature have to take into account pubic law factors when enacting the private law of personal jurisdiction in e-commerce. ${ }^{139}$ This is because the development of the internet is not only important for the national economy, but also has significant implications on fundamental issues, such as national security and political stability. In countries like China, personal jurisdiction in private international law has been dynamically developed as a response to these fundamental issues. This may explain the real legislative goals for jurisdiction based on the location of a server.

\section{A. DATA LocalizATION AND NATIONAL SECURITY}

The Chinese territorial-based personal jurisdiction rule reflects and facilitates data localization requirements in China. China is moving towards economy-wide data localization. ${ }^{140}$ For example, Article 8 of the Provisions on the Administration of Online Publishing Services provides that book, audio-visual, electronic, newspaper, or periodical publishers with online services must localize their servers and storage devices in the territory of China. ${ }^{141}$ Article 27 of the Interim Measures for the Administration of the Business Activities of Online Lending Information Intermediary Institutions requires that the storage, processing, and analysis of information on lenders and borrowers collected within the

\footnotetext{
139 E.g., Maja Brkan, Data Protection and European Private International Law: Observing a Bull in a China Shop, 5 INT'L DATA PRIV. L. 257, 258 (2015) (arguing that the fundamental right to data protection depends on personal jurisdiction that is framed in a way to enable effective judicial enforcement of this right).

${ }^{140}$ L. Scott Livingston and Graham Greenleaf, Data Localisation in China and Other APEC Jurisdictions, 143 PRIVACY L. \& BUS. INT'L REP., Oct. 2016, at 23-26.

${ }^{141}$ Provisions on the Administration of Online Publishing Services (promulgated by the Ministry of Indus. \& Info. Tech., Feb. 4, 2016, effective Mar. 10, 2016) CLI.4.264071(EN) (Lawinfochina.com), art. 8.
} 
territory of China shall be conducted within China. ${ }^{142}$ Unless otherwise provided for by any law or regulation, an online lending information intermediary institution shall not provide information on domestic lenders and borrowers to any party outside of China. ${ }^{143}$ The 2017 China Cybersecurity Law further provides that personal information and important data collected and produced by critical information infrastructure operators during their operations within the territory of China shall be stored within China. ${ }^{144}$ Apple, Microsoft, IBM, and many other non-Chinese internet giants have complied with this law and set up data centers in China. ${ }^{145}$

According to a study conducted by the European Centre for International Political Economy, the data localization requirements may decrease China's GDP by $1.1 \%$, reduce China's exports by $1.7 \%$ due to direct loss of competitiveness, create $\$ 63$ billion of welfare losses, and cut $13 \%$ of the salary of an average worker in China. ${ }^{146}$ Regardless of this cost, however, China is still determined to move towards economy-wide data localization. This is because China believes localization will enhance its control of national cybersecurity. Technologically and economically, storing personal information and important data in different servers around the world (especially in technologically advanced western countries) may provide better security. However, political differences and consequent distrust between China and these countries do not allow China to do so. China, as an economic and political giant, has tremendous financial and human resources to develop its own cybersecurity technology. ${ }^{147}$ A solution for China may be to save

\footnotetext{
${ }^{142}$ Interim Measures for the Administration of the Business Activities of Online Lending Information Intermediary Institutions (promulgated by the Banking Regulatory Comm'n, Ministry of Indus. \& Info. Tech., and Ministry of Pub. Sec., Aug. 17, 2016, effective Aug. 17, 2016) CLI.4.44J0IEX4(EN) (Lawinfochina.com), art. 27.

${ }^{143} I d$.

${ }^{144}$ Cybersecurity Law of the People's Republic of China (promulgated by the Standing Comm. Nat'l People's Cong., Nov. 7, 2016, effective June 1, 2017) CLI.1.283838(EN) (Lawinfochina.com), art. 37 [hereinafter China's Cybersecurity Law].

145 See Paul Mozur, Daisuke Wakabayashi \& Nick Wingfield, Apple Opening Data Center in China to Comply with Cybersecurity Law, N.Y. TIMES (July 12, 2017), https://www.nytimes.com/ 2017/07/12/business/apple-china-data-center-cybersecurity.html (indicating that many international digital giants have built data centers in China in order to fulfill the localization requirement of Chinese Cyber Security Law).

${ }^{146}$ European Centre For International Political Economy, The Costs of Data LOCALISATION: FRIENDLY FIRE ON ECONOMIC RECOVERY (2014).

${ }^{147}$ Central Committee General Office, Opinions Concerning Stimulating the Healthy and Orderly Development of the Mobile Internet, CHINA COPYRIGHT AND MEDIA (Jan. 15, 2017), https://
} 
personal information and important data on different servers within China and impose strict assessment measures for moving this data across borders. Therefore, it is unsurprising that Chinese courts adopt the territorial jurisdiction approach.

\section{B. Applicable Law and Political Stability}

Although internet tort cases mostly involve private rights, misusing the internet may profoundly harm aspects of state public power, such as national value and political stability. "The idea of territoriality itself can be seen as a geographic strategy to control people and things by controlling area ... the power of topography conceals the topography of power." 148 China needs the internet as a dissemination platform to "tell good Chinese stories" and promote socialist values. ${ }^{149} \quad$ Personal jurisdiction based upon the location of a server aims to ensure the application of Chinese law, reinforcement of Chinese values, and ultimately serves the public policy goal of political stability. According to Article 10 of the Provisions on the Administration of internet Information Search Services, an internet information search service provider shall provide objective, impartial, and authoritative search result. ${ }^{150}$ The criteria for "objective, impartial and authoritative" includes national interest, public interest, and socialist values. ${ }^{151}$ Socialist values also apply to whoever provides internet live-streaming services or conducts cyber performance. ${ }^{152}$ Moreover, the China Cybersecurity Law provides that when finding any information of which the release or transmission is prohibited by any law or administrative regulation, the National Cyberspace Administration will require the relevant network operator to cease transmission, make deletions or any other handling

chinacopyrightandmedia.wordpress.com/2017/01/15/opinions-concerning-stimulating-thehealthy-and-orderly-development-of-the-mobile-internet/.

148 Zekos, supra note 7, at 8.

149 Central Committee General Office, supra note 147, para. 20.

${ }^{150}$ Provisions on the Administration of Internet Information Search Services (promulgated by State Internet Info. Office, June 25, 2016, effective Aug. 1, 2016) CLI.4.42NAPC4G(EN) (Lawinfochina.com).

151 See id.

152 Provisions of the Administration of Internet Live-Streaming Services (promulgated by State Internet Info. Office, Nov. 4, 2016, effective Dec. 1, 2016) CLI.4.453PCTJ6(EN) (Lawinfochina.com), art. 3; Notice of the Ministry of Culture on Issuing the Measures for the Administration of Cyber Performance Business Operations (promulgated by the Ministry of Culture, Dec. 2, 2016, effective Jan. 1, 2017) CLI.4.45ELAICU(EN) (Lawinfochina.com), art. 3. 
measures, and preserve relevant records. ${ }^{153}$ If the aforesaid information comes from outside of China, the National Cyberspace Administration shall notify the relevant institution to take technological and other necessary measures to block the transmission of the information. ${ }^{154}$ Chinese courts can more easily enforce this law if the server is located in its jurisdiction.

\section{CAN THIS TERRITORIAL-BASED PERSONAL JURISDICTION RULE SUCCESSFULLY FULFILL ITS LEGISLATIVE GOALS?}

The practical impact of this rule needs further observation because Chinese plaintiffs (i.e., infringees) can often bring an internet tort case in their domicile and need not invoke jurisdiction based on the server. Jurisdiction based on the location of the server likely deters foreign cloud computing companies to deploy their data centers in China. Furthermore, it may be considered an exorbitant jurisdiction ground under international law.

\section{A. Plaintiffs' Domicile Versus The Location of the Server}

Article 25 of the 2015 Judicial Interpretation of Civil Procedure Law provides that in cases where the tort occurs over the internet, the place where the result of tort occurs includes the victim's domicile and the court can exercise jurisdiction accordingly. ${ }^{155}$ Plaintiffs are often the victims of the tort. If they have a domicile in China, they usually invoke Article 25 of the 2015 Judicial Interpretation of Civil Procedure Law and bring the case in their domicile. Compared with the place where the defendant's server is located, the plaintiff's domicile often provides better home court benefits to the plaintiff. For example, in Shenzhen Huishenwang Information Technology Co. Ltd. v. Hou Jian Jiang, Hou brought a copyright infringement case against Huishenwang in his domicile, Beijing. ${ }^{156}$ The defendant challenged the court's jurisdiction and requested the court to transfer the case to the court in the location of

\footnotetext{
${ }^{153}$ China's Cybersecurity Law, supra note 144, art. 50.

${ }^{154} \mathrm{Id}$.

${ }^{155} \mathrm{Id}$.

${ }^{156}$ Shenzhenshi Huishen Wang Xinxi Keji Youxian Gongsi Yu Hou Jianjiang Qinhai Zuopin Xinxi Wangluo Chuanboquan Jiufenan (深性帅汇深㳔㴧科技有限公司与侯建仜侵害作品信息网络传播叔纠 纷案 [Shenzhen Huishenwang Info. Tech. Co. v. Hou Jian Jiang], Jing 73 MiN XIA ZHONG No. 76 (Beijing IP Ct. Mar. 22, 2018) (China).
} 
its server or its domicile. ${ }^{157}$ The Beijing IP Court rejected the defendant's challenge, holding that it had jurisdiction because the plaintiff's domicile was the place where the tort occurs. ${ }^{158}$

The issue is whether Article 25 of the 2015 Judicial Interpretation of Civil Procedure Law can be applied to online infringements of patents and trademarks. This is because SPC's judicial interpretations for online infringements of patent and trademark disallow the court at the plaintiff's domicile to exercise jurisdiction merely based on the fact that the court is located in the plaintiff's domicile. The Certain Provisions of the SPC on Issues Concerning Application of Law in Trying Cases Involving Patent Disputes provides that patent infringement shall be under the jurisdiction of the people's court at the place of infringement or the place of the defendant's domicile. ${ }^{159}$ The place of infringing activities shall include: the place where products alleged to infringe upon invention patents or utility model patents are manufactured, used, offered for sale, sold, imported, etc.; the place where patented methods are implemented, and the place where products directly obtained by virtue of the said patented methods are used, offered for sale, sold, imported, etc.; the place where products with design patents are manufactured, offered for sale, sold, imported, etc.; the place where counterfeiting of the patents of others is committed; and, the place where the consequences of the foregoing infringing activities occur. ${ }^{160}$ Accordingly, the plaintiff's domicile is neither the place of infringement activities occur nor the consequences of the infringement. However, some Chinese courts have interpreted the place of sale, in online patent infringement cases, includes the place of receiving the goods. ${ }^{161}$ The

\footnotetext{
${ }^{157} I d$.

${ }^{158}$ Id. Another similar case is Chenvuexian Yu Beijing Baidu Wang Xun Keji Youxian Gongsi Wangluo Qinquan Zeren Jiufen An (陈月仙与北京百度刚讯科技有限公司劝络侵权责任纠纷案) [Chen Yue Xian v. Beijing Baidu Co.], Yue 0306 Min ChU No. 19925 (Shenzhen Baoan Dist. People's Ct. Sept. 1, 2017) (China).

${ }^{159}$ Several Provisions of the Supreme People's Court on Issues concerning the Application of Law in the Trial of Cases on Patent Disputes, (promulgated by the Sup. People's Ct., Jan. 29, 2015, effective Feb. 1, 2015) CLI.3.242360(EN) (Lawinfochina.com), art. 5.

${ }^{160} \mathrm{Id}$.

${ }^{161}$ For example, in Shenzhen Honglou Jiaju Co. v. Ye Zhi Xiang, the Guangdong High People's Court held that online sale is a cross-regional activity conducted through an online sale platform, and a complete transaction process includes the buyer placing an order, the seller delivering the goods, and the buyer receiving the goods, so the place where the buyer receives the goods should be considered a place of sale. Shenzhen Shi Honglou Jiaju Youxian Gongsi, Yezhixiang Qinhai Waiguan Shejì Zhuanlì Quan Jiufen An (深纱红楼家居有限公司、叶志祥骎害外观设计专利淑纠纷 案) [Shenzhen Honglou Jiaju Co. v. Ye Zhi Xiang], YuE MiN XIA ZHONG No. 225 (Guangdong High People's Ct. Apr. 10, 2018) (China).
} 
latter may be the plaintiff's domicile. This creates the potentials for the courts at the plaintiff's domicile to exercise jurisdiction.

Regarding trademark, Article 6 of the Interpretation of the SPC Concerning the Application of Laws in the Trial of Cases of Civil Disputes Arising from Trademarks (hereinafter "SPC Trademark Judicial Interpretation") also excludes the plaintiff's domicile as the place of the infringement. ${ }^{162}$ However, the implementation of the SPC Trademark Judicial Interpretation in practice is split. Many courts hold that Article 25 of the 2015 Judicial Interpretation of Civil Procedure Law can be applied to online trademark infringement so the court at the plaintiff's domicile can exercise jurisdiction. For example, in Beijing Baidu Co. Ltd. v. Shenzhen FangxiangPan Wangluo Co. Ltd. et al., Baidu argues that the SPC Trademark Judicial Interpretation should be applied to determine the jurisdiction of the case. ${ }^{163}$ The Chongqing High People's Court rejected this argument and applied the 2015 Judicial Interpretation of Civil Procedure Law. ${ }^{164}$ The Court held that the court at the infringee's domicile should have jurisdiction. ${ }^{165}$ The argument for this practice is that, although the SPC Trademark Judicial Interpretation is lex specialis, the 2015 Judicial Interpretation of Civil Procedure Law is lex posterior and should derogate lex priori. However, the 2015 Judicial Interpretation

${ }^{162}$ See SPC on Civil Disputes Arising from Trademarks, supra note 102, art. 6. "A civil action instituted on the ground that the exclusive right to use a registered trademark has been infringed upon shall be subject to the jurisdiction of the people's court where the infringing act is carried out, where the infringing commodities are stored or sealed up and detained, or where the defendant has his domicile as is provided for in Articles 13 and 52 of the Trademark Law. The place where infringing commodities are stored as provided in the preceding paragraph refers to the place where large quantities of infringing commodities are stored or hidden or infringing commodities are regularly stored or hidden. The place of sealing up and detention refers to the place where the administrative departments such as the customs office and the administration for industry and commerce, etc. lawfully seal up or detain the infringing commodities." Id.

${ }^{163}$ Beiiing Baidu Wang Xun Keii Youxian Gongsi Yu Shenzhen Shi Fangxiangpan Wangluo Keji Youxian Gongsi Deng Bu Zhengdang Jìngzheng Jiufen An (北京百度叒讯科技有限公司与深师市方向 盘网络科技有限公司等不正当竞争纠纷案) [Beijing Baidu Co. v. Shenzhen FangxiangPan Wangluo Co.], Yu Min Xia Zhong No. 60 (Chongqing High People's Ct. June 12, 2018) (China). See also. Beiiing Baidu Wang Xun Keii Youxian Gongsi Yu Chongqing Mage Jiaju Youxian Gongsi Deng Qinhai Shangbiao Quan Jiufen An (北京百度双讯科技有限公司与重庆玛格家居有限公司等侵害商 标权纠纷案) [Beijing Baidu Co. v. Chongqing Mage Jiaju Co.], YU MiN XIA ZHONG No. 74 (Chongqing High People's Ct. July 13, 2018) (China); Chongqing Zhubajie Wangluo Youxian Gongsi Yu Beijing Baidu Wang Xun Keji Youxian Gongsi Qinhai Shangbiao Quan Jiufen An (重 庆猪八戒双络有限公司、北京百度网讯科技有限公司侵害商标权纠纷案) [Chongqing Zhubajie Wangluo Co., Beijing Baidu Co. v. Shenzhen Jingying Trademark Firm], Yue Min XiA Zhong No. 851 (Guangdong High People's Ct. Dec. 22, 2017) (China).

${ }^{164}$ Beijing Baidu Co. v. Shenzhen FangxiangPan Wangluo Co., YU Min XIA ZHOng No. 60 (Chongqing High People's Ct. June 12, 2018).

${ }^{165} \mathrm{Id}$. 
of Civil Procedure Law is lex generali and its Article 25 does not specially deal with trademark infringements, and although it is enacted much more recently than the SPC Trademark Judicial Interpretation, it is hard to justify that the former should prevail over the latter in case of conflicts. Notably, in a judgment rendered in 2017, the SPC holds that Article 25 of the 2015 Judicial Interpretation of Civil Procedure Law should not be applied to determine the jurisdiction of a court in online trademark infringement and the SPC Trademark Judicial Interpretation should be applied. This case is Foshan Nanhai Beihao Biological Science Co. Ltd. v. Tianjin Meizilu Cosmetic Co Ltd. ${ }^{166}$ The plaintiff brought a trademark infringement and unfair competition case in its domicile, Foshan City. ${ }^{167}$ The Foshan Court applied the SPC Trademark Judicial Interpretation and hold that it had no jurisdiction. ${ }^{168}$ The plaintiff appealed to the Guangdong High Court. ${ }^{169}$ The Guangdong High Court held that the Foshan Court should have jurisdiction, so it asked the SPC's opinion. ${ }^{170}$ The SPC held that, according to the SPC Trademark Judicial Interpretation, the court in Foshan City had no jurisdiction because it was neither the place where the tort activity occurred nor the place where the infringing products were stored or seized. ${ }^{171}$ Article 25 of the 2015 Judicial Interpretation of Civil Procedure Law should not be applied. ${ }^{172}$ However, Foshan Nanhai Beihao Biological Science Co. Ltd. v. Tianjin Meizilu Cosmetic Co. Ltd. has not been listed as a guiding case by SPC, ${ }^{173}$ so it apparently has no binding force for lower courts and some cases decided after it has not followed it thus far. An example in point is the Chongqing High Court in Beijing Baidu Co. Ltd. V. Shenzhen FangxiangPan Wangluo Co. Ltd. et al.

Therefore, because of Article 25 of the 2015 Judicial Interpretation of Civil Procedure Law, in internet tort cases other than

${ }^{166}$ Foshan Nanhai Beihao Biological Science Youxian Gongsi Yu Tianjin Meizilu Cosmetic Youxian Gongsi Qinhai Shangbiao Quan Jiufen An (佛山市南海贝豪生物科技有限公司与天津美之路化 妆品有限公司侵害敵标权纠纷案) [Foshan Nanhai Beihao Biological Sci. Co. v. Tianjin Meizilu Cosmetic Co.], Zui Gao FA Min XIA No. 29 (Sup. People's Ct. Nov. 21, 2017) (China).

${ }^{167} I d$.

${ }^{168} I d$.

${ }^{169} I d$.

${ }^{170} \mathrm{Id}$.

${ }^{171} I d$.

${ }^{172} I d$.

${ }^{173}$ See Notice of the Supreme People's Court on Issuing the Provisions on Case Guidance (promulgated by the Sup. People's Ct., Nov. 26, 2010, effective Nov. 26, 2010) CLI.3.143870(EN) (Lawinfochina.com), art. 7. 
infringements of patents and trademarks, a plaintiff can bring actions in its domiciles. Only in rare cases where the plaintiff does not want to bring cases in its domicile and wants to avoid the defendant's home court advantage, the plaintiff may want to invoke the jurisdiction of the court in the location of the servers. In cases of patents and trademarks infringements, the plaintiff is likely to be permitted to bring cases in their domiciles. Generally, when it is not allowed to do so (as Foshan Nanhai Beihao demonstrates), the court in the place of the server may be an alternative to avoid litigating in the defendant's home court if the place of the server is different from the defendant's domicile. Therefore, the role of the jurisdiction based on the location of the server is limited in practice.

Moreover, jurisdiction based on the location of the server has been strategically used by a foreign plaintiff that has no domicile in China to bring an action against a large Chinese company outside of the latter's domicile. An example is Rockwool International A/S v. Dalian Rockwool Co Ltd. ${ }^{174}$ Rockwool International A/S, a Danish company (hereinafter "Danish Rockwool"), had been a leading producer of insulation, fireproofing and other products made with stone wool since 1937. ${ }^{175}$ Danish Rockwool began selling its products to Chinese buyers in 1995. ${ }^{176}$ Its products were sold in China under the ROCKWOOL trademark, which was registered in China in 2013. ${ }^{177}$ Dalian Rockwool Co. Ltd. (hereinafter "Chinese Rockwool") was a Chinese company, established in Dalian City in Liaoning Province. ${ }^{178}$ Since 1987, it had used "Rockwool" in its name, its website (www.chinarockwool.com), as well as its headquarter and factory signage. Danish Rockwool viewed these uses of its trademark as unauthorized infringement. ${ }^{179}$ Chinese Rockwool contracted with a third-party service provider to operate its website. ${ }^{180}$ The server was located in Jiangmen City, Guangdong Province and the third-party service provider was also registered there. ${ }^{181}$

\footnotetext{
${ }^{174}$ Rockwool International A/S Su Dalian Yanmian Youxian Gongsi Qinhai Shangbiaoquan Ji Buzhengdan Jingzheng An (洛克尔国际有限公司诉大连岩棉有限公司侵害商标权及不正当 纠纷案) [Rockwool Int'l A/S v. Dalian Rockwool Co.], JiANG ZHONG FA ZHI MIN CHU ZI No. 95 (Jiangmeng Interm. People's Ct. Jan. 16, 2016) (China).

${ }^{175} \mathrm{Id}$.

${ }^{176} I d$.

${ }^{177} I d$.

${ }^{178} I d$.

${ }^{179} \mathrm{Id}$.

${ }^{180} \mathrm{Id}$.

${ }^{181} I d$.
} 
Danish Rockwool did not want to sue Chinese Rockwool in the latter's domicile, perhaps in fear of local protectionism. So, it filed a suit in the Intermediate People's Court in Jiangmen City alleging trademark infringement against Chinese Rockwool. ${ }^{182}$ The Jiangmen court accepted the case based upon the location of the server and ruled favorably for Danish Rockwool. ${ }^{183}$ The court ruled that the location of the server was where the trademark infringement was committed. ${ }^{184}$ Rockwool International $A / S$ may not be consistent with the intended legislative goal of this "patriotic" jurisdiction rule.

\section{B. Deterritorial NATURe OF Cloud COMPuting}

The development of cloud computing may significantly challenge this jurisdiction rule. Cloud computing is delocalized. ${ }^{185} \mathrm{It}$ allows for "on-demand 'scalability' of computing power by end users that are located remotely from the computing resources themselves." 186 Moreover, most cloud services maintain data on multiple servers in separate locations. ${ }^{187}$ "This is an excellent redundancy, should there be an internet outage or data center disaster. The data is readily available from the other cloud locations without an interruption in service." 188 In cloud computing, websites may contain elements stored on multiple servers, which can be changed when required by businesses, and internet users are rarely aware of the locations or changes of the servers when conducting electronic transactions. ${ }^{189}$

As the High Court of Australia in Dow Jones \& Company Inc $v$. Gutnick describes:

"[A]dventitious" and "opportunistic" are words likely to produce considerable debate. Does a publisher's decision to have a server in a country where the costs of operation are low, or the benefits offered for setting up business are high, warrant either of these descriptions? Does a publisher's decision to have servers in two, widely separated, states or even countries warrant either description, or is it simply a

\footnotetext{
${ }^{182} I d$.

${ }^{183} \mathrm{Id}$.

${ }^{184} \mathrm{Id}$.

${ }^{185}$ Definition of Cloud Computing, AMERICAN NATIONAL InSTITUTE OF STANDARD AND TECHNOLOGY (Oct. 6, 2017), http://csrc.nist.gov/groups/SNS/Cloud-computing/. 
prudent business decision to provide security and continuity of service? How is the user to know which server dealt with a particular request? Is the fact that one rather than the other server met the request "adventitious"? 190

Therefore, the High Court rejected the view that the law applicable to online defamation cases should be governed by the law of the place where the defendant publisher maintained its web servers. ${ }^{191}$ Instead, it applied the law of the place where the plaintiff-victim downloaded the infringing material. ${ }^{192}$ The same logic applies to personal jurisdiction in cloud computing. An internet tort in the cloud context may involve simultaneous data transfer from several servers in different locations. If the cloud is provided by a third party, the infringer may not even know which servers operate his infringing contents. The location of the server becomes insignificant for the tort. China has put tremendous efforts to develop cloud computing. This territorial-based jurisdiction rule may deter foreign cloud providers to build their data centers in China.

\section{EXORBITANT JURISDICTION}

Section 207 of the ALI Principles provides that "jurisdiction ... is insufficient when exercised solely on the basis of the presence in that State of tangible property belonging to the defendant, except when the dispute is directly related to that property (emphasis added)." ${ }^{193}$ Similarly, the Preliminary Draft Convention on Jurisdiction and Foreign Judgments in Civil and Commercial Matters adopted by the HCCH Special Commission in 1999 (hereinafter "1999 Preliminary Draft Convention") provides that courts are prohibited from exercising jurisdiction solely based on the presence or the seizure in that state of property belonging to the defendant, except where the dispute is directly related to that property. ${ }^{194}$ The International Law Association IP and Private International Law Committee is drafting Guidelines on IP and

\footnotetext{
${ }^{190}$ Dow Jones \& Co v Gutnick (2002) 210 CLR 575, para 11 (Austl.).

${ }^{191} I d$.

${ }^{192} I d$.

${ }^{193}$ Intellectual Property: Principles Governing Jurisdiction, Choice of LAW, AND JUDGMENTS IN TRANSNATIONAL DisPUTES $§ 207$ (AM. LAW. INST. 2008).

${ }^{194}$ Permanent Bureau of the Hague Conference on Private International Law, Draft Convention on Jurisdiction and Foreign Judgments in Civil and Commercial Matters, art. 18(2)(a) Preliminary Document No. 11 (2000).
} 
Private International Law to harmonize jurisdiction, choice of law, recognition and enforcement of judgments and arbitral awards. ${ }^{195}$ In the drafted Guidelines, insufficient grounds for jurisdiction include jurisdiction solely based on the presence in the forum of property belonging to the defendant, except when the dispute is directly related to that property. ${ }^{196}$ The question is whether internet tort is directly related to the server that uploads, dispatches or downloads the infringing contents so that the location of the server provides a sufficient nexus with the forum to assert jurisdiction. The 1999 Preliminary Draft Convention does not define "directly related to" and its meaning may be left to domestic laws. ${ }^{197}$ The existing ECJ jurisprudence answers "no" to the question. ${ }^{198}$ The United States courts also answer negatively, except where infringement constitutes an illegal trespass to the server. ${ }^{199}$ In Australia, this question may also attract a negative response unless a statute requires otherwise. ${ }^{200}$ Therefore, the Chinese territorial-based jurisdiction rule is a minority and may be considered an exorbitant jurisdiction by international law.

\section{CONCLUSION AND PROPOSAL}

Whether personal jurisdiction can be exercised based solely on the location of a server is a question that is increasing in importance and its impacts on the development of new digital economy are deserving of attention. This territorial-based jurisdiction rule is consistent with China's nationwide data localization requirement. However, this rule may have limited functions in practice, because in most of internet tort cases the plaintiffs do not need to invoke it to haul a foreign defendant into a Chinese court. Article 25 of the 2015 SPC Judicial Interpretation of Civil Procedure Law allows the plaintiffs to bring cases in their domicile. This rule does not support the a-territorial nature of cloud computing. It may be considered as exorbitant under international law.

\footnotetext{
195 InTERNATIONAL LAW ASSOCIATION, INTELLECTUAL PROPERTY AND PRIVATE INTERNATIONAL LAW (2018), http://www.ila-hq.org/images/ILA/DraftReports/DraftReport_Intellectual Property.pdf (last visited Oct. 2, 2018).

${ }^{196}$ Id. art. 16(a).

197 TOSHIYUKi Kono, InTEllectual Property AND PRIVATE INTERNATIONAL LAW: COMPARATIVE PERSPECTIVES 49 (2010).

${ }^{198}$ See supra Part II.

${ }^{199}$ See supra Part IV

${ }^{200}$ See supra Part III
} 
Therefore, Chinese legislature may consider to combine the location of the server with the "directed" factors, which means that the infringer must target the forum state and expect the harm to occur in that state. Except in the cases of illegal transmission of emails and domain name registration disputes, the mere location of a server should not be considered the place where the tort occurs. 